\title{
Configuration Monitoring Technology based PLC Practical Teaching Device
}

\author{
Yingjie $\mathrm{Hu}$ \\ Shanghai University of \\ Engineering science \\ Songjiang Shanghai \\ 201620, China
}

\author{
Jingzhi Zhang \\ Shanghai University of \\ Engineering science \\ Songjiang Shanghai \\ 201620, China
}

\author{
Yuchen Liang \\ Shanghai University of \\ Engineering science \\ Songjiang Shanghai \\ 201620, China
}

\author{
Zhuohao Li \\ Shanghai University of \\ Engineering science \\ Songjiang Shanghai \\ 201620, China
}

\begin{abstract}
This paper aims at analyzing the design and the realization process of PLC practical teaching device developed by the configuration technology. Specifically, this practical teaching device employs the teaching monitoring interface developed by the configuration software to communicate with the programmable controller so as to realize such functions as system login, question type selection and operation control for the teaching and assessing process. Meanwhile, the system function and structure, the hardware layout design, the material model selection, the system flow, PLC input-output terminal distribution, the configuration monitoring interface design, the array library dictionary construction and the monitoring process design are particularly described in this paper.
\end{abstract}

\section{Keywords}

Configuration Monitoring Technology, Programmable Controller, Practical Teaching Device

\section{INTRODUCTION}

PLC technology application is an important content for the skill level appraisal of maintenance electricians, but the assessing equipment has relatively low automation and many human factors also seriously influence assessment fairness and quality. This system employs the secondary development of Kingview upper computer software to not only modularize and integrate the teaching content for the multiple use in this system, but also automatically set faults and detect troubleshooting operations, thus to solve fairness problem. Moreover, this practical teaching device, which can meet the requirements of Shanghai Municipal Human Resources and Social Security Bureau for relevant skill appraisal and assessment, employs the configuration technology to realize the function of student information login, and combines pictures, animations, words and analog simulation to realize the human-computer interaction of the configuration monitoring interface during PLC assessing and teaching process.

\section{SYSTEM FUNCTION DESCRIPTION}

This device aims at simulating the running state of the industrial field equipment and mainly employs human-computer interface for the information interaction with lower computer PLC, thus to not only enable PLC peripheral input signal to control the output state, but also enable the upper computer to control PLC output for realizing remote control. Ten sets of typical projects regarding equipment maintenance and debugging are mainly integrated for the system development in order to enable the students to independently carry out computer debugging, thus to improve their programming ability and operability. The system composition block diagram is as shown in Fig. 1.

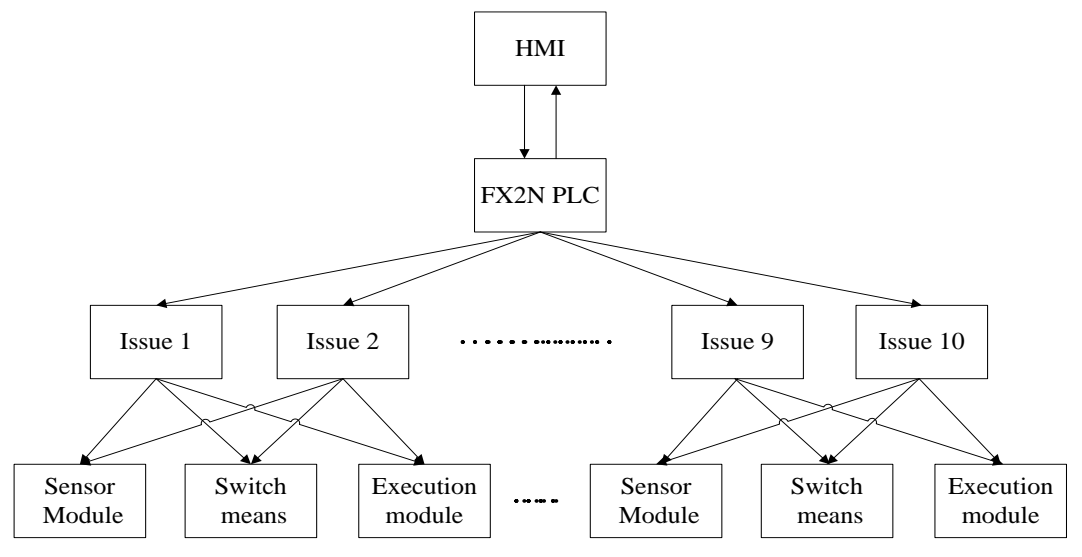

Fig. 1 System Block Diagram

Due to the limitation of PLC input-output count and the platform, for the consideration of beautiful appearance of the platform, this practical teaching device employs two projects --- forward-reversion operation and responder as an example for relevant demonstration under the precondition of realizing the primary function. 
The design requirement for realizing PLC based forwardreversion operation of three-phase asynchronous motor is as follows: when the forward button SB1 is pressed, the contactor KM1 will be connected to the motor to enable it to execute forward, and the rotating direction of the motor shall not be reversed within $5 \mathrm{~s}$ after the forward operation of the motor; in other words, the reversion button SB2 shall not be pressed within the specified time, and the motor shall still keep the forward operation. When the reversion button SB2 is pressed, the contactor KM2 will be connected to the motor to enable it to execute reversion operation, and similarly, the motor shall not be reversed within $5 \mathrm{~s}$ after the reversion operation of the motor. When the stop button SB3 is pressed, the motor stops running.

The design requirement for realizing PLC based contest responder device is as follows: the moderator shall be able to control the two responder tables through pressing button SB3. After the moderator gives out the topic and meanwhile presses the responder button SB3, the competitive answering activity shall be started. The indicator light of the table of which the responder button is firstly pressed shall be turned on and meanwhile the buzzer shall be connected, and the subsequent competitive answer shall be invalid. After 5s' delay, the buzzer shall stop working and meanwhile the answering indicator light shall be turned on, wherein the answering time is $5 \mathrm{~s}$, and afterwards, the responder indicator light and the answering indicator light shall be automatically turned off. In case nobody presses the responder button within $5 \mathrm{~s}$, the competitive answering activity shall be ended.

\section{SYSTEM HARDWARE DESIGN}

According to the system requirements and the function requirements, the layout of the platform design of the whole practical teaching device is as shown in Fig. 3. In the figure, the middle part is the control system, RS-232 communication mode is adopted between PC and the programmable controller; the left part is the responder actuator and the right part is the forwardreversion control actuator, and the above two parts are connected with PLC through terminal block interface, thus to modularize the system and facilitate system management, module replacement and device maintenance. Fig. 2 is the physical phone of the device. Models and functions of the components of the device are as shown in Table 1.

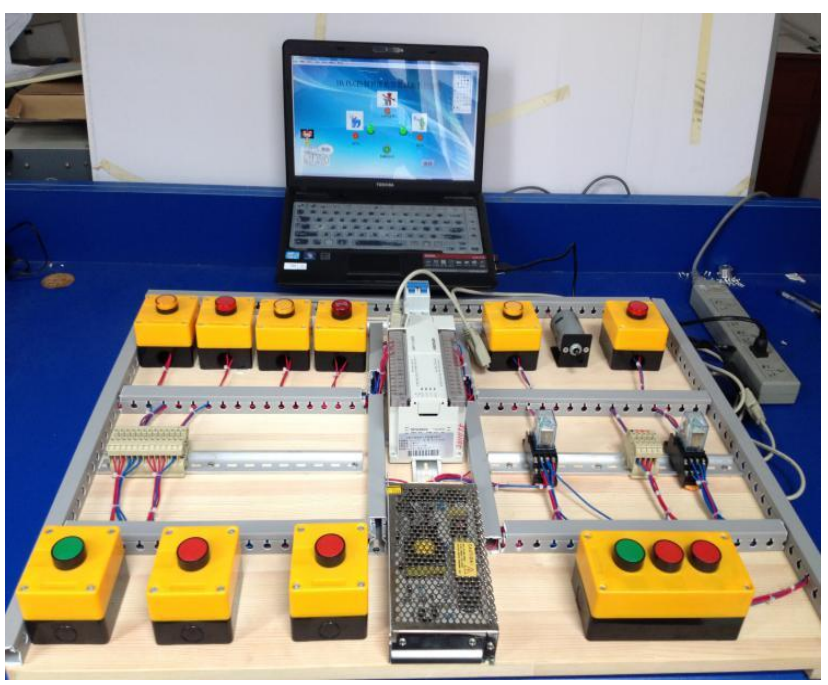

Fig. 2Physical Photo of the Device

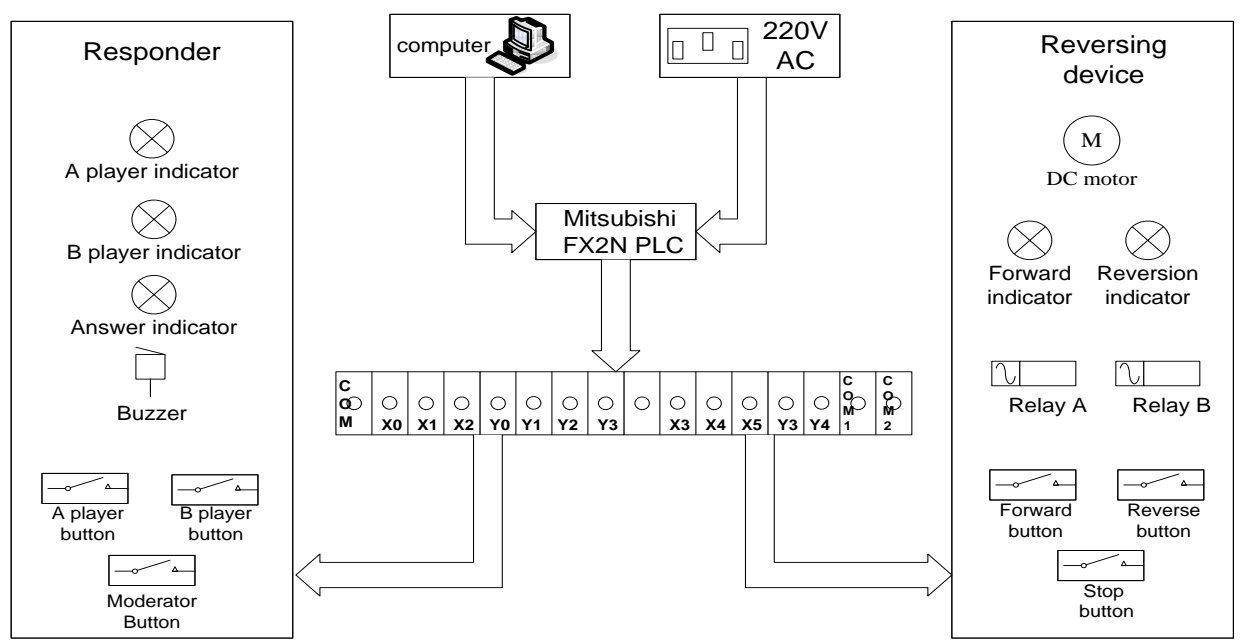

Fig. 3 System Structure Drawing

Table 1 Component Functions Table

\begin{tabular}{|c|c|l|}
\hline Component & Model & \multicolumn{1}{c|}{ Functional Features } \\
\hline PLC & Mitsubishi FX-2n & $\begin{array}{l}\text { Rapid program execution; simple, flexible and convenient } \\
\text { programming; comprehensive supplementation for communication } \\
\text { function; maximum control power. }\end{array}$ \\
\hline Terminal block & $\begin{array}{c}\text { SAK2.5/EN guide rail } \\
\text { installation }\end{array}$ & Convenience and simple operation of guide rail installation. \\
\hline Motor & 775 DC motor & $\begin{array}{l}\text { Rated voltage: } 12 \mathrm{~V}-24 \mathrm{~V} ; \text { no-load current: } 0.2 \mathrm{~A} ; \text { no-load speed: } \\
1800-7200 \mathrm{rmp} / \mathrm{min} ; \text { weight: } 300 \mathrm{~g} .\end{array}$ \\
\hline
\end{tabular}




\begin{tabular}{|c|c|c|}
\hline Buzzer & AD16-22SM 22MM & $\begin{array}{l}\text { Power frequency withstand voltage: } 2.5 \mathrm{KW} \mathrm{AC}, 1 \mathrm{~min} \text {; } \\
\text { Insulation resistance: }>2 \mathrm{M} \Omega\end{array}$ \\
\hline \multirow[t]{2}{*}{ LED indicator } & \multirow[t]{2}{*}{ AD16-22DS } & $\begin{array}{ll} & \text { (1) Forward indicator } \\
\text { Yellow } & \text { (2) A player indicator } \\
& \text { (3)Answer indicator }\end{array}$ \\
\hline & & $\begin{array}{l}\text { (1) Reversion indicator } \\
\text { Red } \\
\text { (2) B player indicator }\end{array}$ \\
\hline \multirow[b]{2}{*}{ Button } & \multirow[b]{2}{*}{ 3.1.1 XB2-EA135 } & $\begin{array}{ll} & \text { (1)Forward button } \\
\text { Green } & \text { (2) B player indicator }\end{array}$ \\
\hline & & $\begin{array}{l}\text { (1) Reversion button } \\
\text { (2) Stop button } \\
\text { (3) Moderator button } \\
\text { (4A player indicator }\end{array}$ \\
\hline
\end{tabular}

\section{SYSTEM PLC PROGRAMMING}

\subsection{System Flowchart}

In the software design, the system shall be firstly initialized and then the students can enter the login interface and input their own student IDs and passwords to $\log$ in the system. In the human-computer interface, 10 sets of typical projects are arranged, and for the testing projects, the students can click the project button to enter corresponding project operating interface.
For PLC programming in GX Developer, after the program is downloaded to PLC, the students can power on PLC according to the operating requirement, wherein if the program is correct, then the online execution is available; or else, the program shall be inspected and corrected for another test till the online execution is successful. The flowchart drawn according to the system control requirement is as shown in Fig. 4.

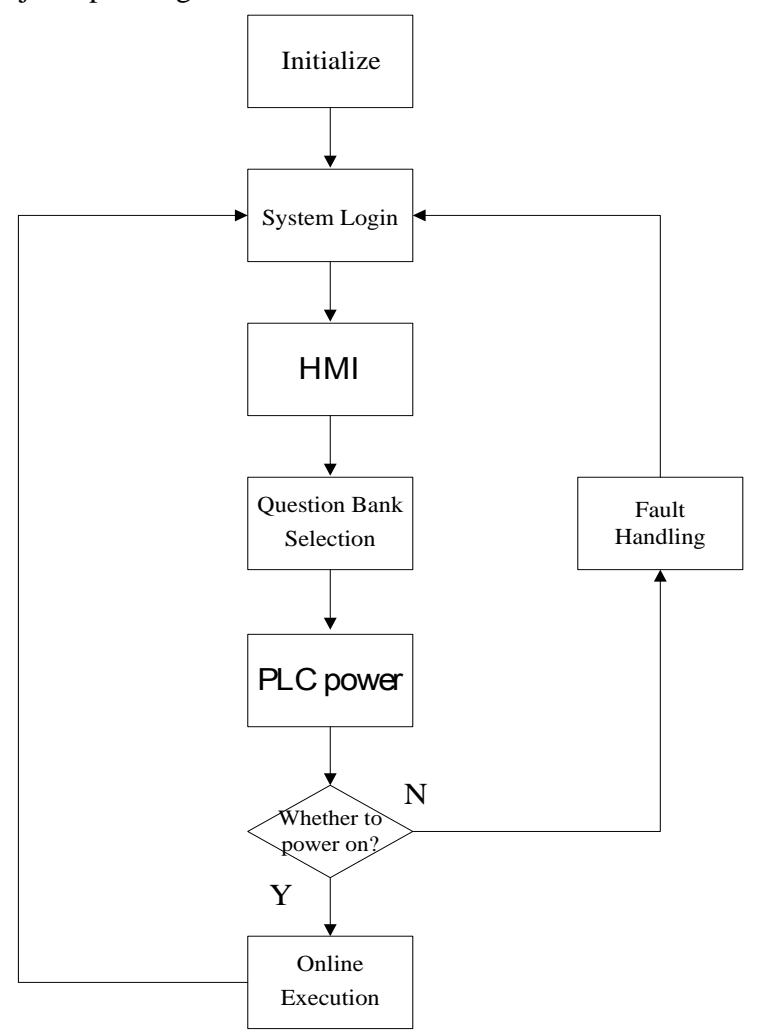

Fig. 4 System Flowchart

\subsection{System PLC I/O distribution list}

I/O distribution list shall be firstly given according to system requirements, as shown in Table 2, and then PLC can be programmed according to the control technology requirements. 
Table 2 PLC I/O Distribution List

\begin{tabular}{|c|c|c|c|}
\hline \multicolumn{2}{|c|}{ Input/I } & \multicolumn{2}{c|}{ Output/O } \\
\hline Moderator button & $\mathrm{X} 0$ & Buzzer & $\mathrm{Y} 0$ \\
\hline A Player & $\mathrm{X} 1$ & A player indicator & $\mathrm{Y} 1$ \\
\hline B Player & $\mathrm{X} 2$ & B player indicator & $\mathrm{Y} 2$ \\
\hline $\begin{array}{c}\text { Forward-reversion } \\
\text { stop button }\end{array}$ & $\mathrm{X} 5$ & Answer indicator & $\mathrm{Y} 3$ \\
\hline Forward & $\mathrm{X} 3$ & Forward KM1 & $\mathrm{Y} 4$ \\
\hline Reversion & $\mathrm{X} 4$ & Reversion KM2 & $\mathrm{Y} 5$ \\
\hline
\end{tabular}

\section{CONFIGURATION MONITORING DESIGN}

The configuration software for the upper monitoring computer can provide visual monitoring interface, field real-time monitoring function and real-time simulation operation. Specifically, the Kingview software developed by Beijing Wellintech Development Co., Ltd is adopted for this practical teaching device in order to design and develop the monitoring interface with real-time field monitoring and controlling function.

\subsection{Graphic Interface Design}

The practical teaching monitoring system is designed with 15 interfaces, such as "Login Interface", "Operating Project Selection Interface" and "Project Operating Interface", wherein "Login Interface", "Operating Project Selection Interface" and "Forward-Reversion Interface" are as shown in Fig. 5. Specifically, such buttons as forward button, stop button, start button and forward-reversion indicators are modeled in the "Forward-Reversion Operating Interface"; moderator button, A player button and B player button, various indicators, etc. are modeled in the "Responder Operating Interface".

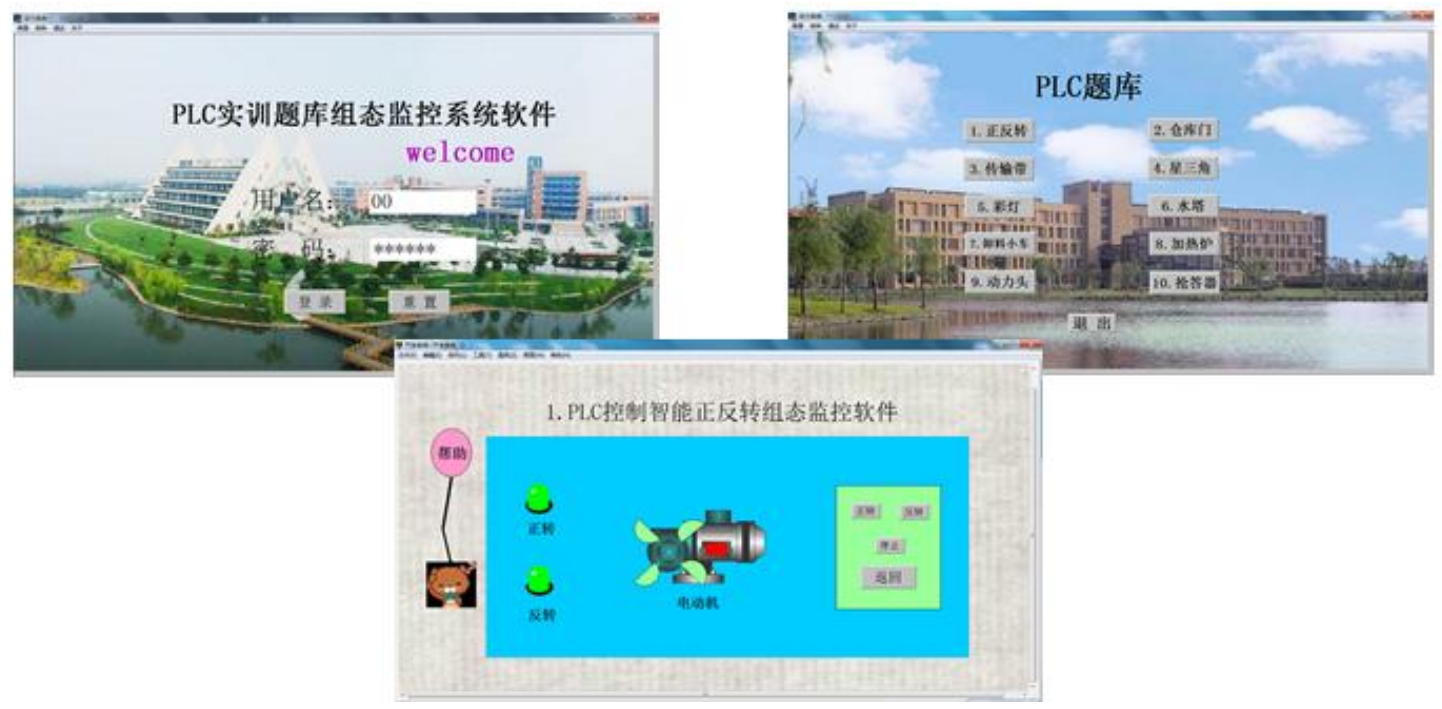

Fig. 5 Graphic Interface

\subsection{Construction of System "data dictionary"}

In the Kingview monitoring system, the database is the core of the whole software, and the data exchange between the graphic interface and I/O drive program can be realized through data variable, wherein the database variable is defined in the "data dictionary", and corresponding variable name is established in the database according to PLC I/O distribution list in Table 2 in order to realize the information exchange with PLC, as shown in Fig. 6. During system program execution, when I/O variable value is changed, such change will be automatically written in remote PLC memory, and when PLC variable is changed, I/O variable in Kingview will be automatically updated. 


\begin{tabular}{|c|c|c|c|}
\hline \$年 & \$月 & \$日 & $\$$ \$时 \\
\hline \$分 & \$秒 & \$日期 & W \$时间 \\
\hline \$用户名 & \$访问权限 & \$启动历史记录 & 世 \$启动报警记录 \\
\hline \$启动后台命令语言 & \$新报警 & \$双机热备状态 & 以\$宣秒 \\
\hline \$网络状态 & 用户名 & 密码 & $\mathrm{dl}$ \\
\hline 正反转 & 登录用户名 & 重置 & 退出 \\
\hline 汳回 & 汳回 1 & 上电 & 旋转1 \\
\hline 旋转2 & 旋转3 & 旋转4 & 正转 \\
\hline 旋转角度 & 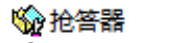 & 汳回2 & 如主持人按钮 \\
\hline 停止 & 正转指示灯 & 则反转指示灯 & 选手A指示灯 \\
\hline 选手B指示灯 & 管题指示灯 & 俈选手A徖䂑 & 以选手B按钮 \\
\hline 反转 & 的蛙鸣器 & 传揄带 & 返回3 \\
\hline 设回4 & 星三角 & 返回5 & 彩灯 \\
\hline 㑑用户名1 & 密码1 & 水塔 & 返回 6 \\
\hline 卸料小车 & 诉回7 & 加热炉 & 设回8 \\
\hline 动力头 & 返回 9 & 蚂令库门 & 汳回10 \\
\hline 帮助 & 帮助1 & 物块 & 启动 \\
\hline 点击进入 & 帮助2 & 以新建... & \\
\hline
\end{tabular}

Fig. 6 Data Dictionary

\subsection{Animation Connection}

Animation connection means the establishment of the relation between the variables in the database and the picture elements in the graphic interface. Through such animation connection, the bilateral control and the simulation run of the graphic interface and the physical object PLC can be realized. For the example of the "Responder" in the "PLC Question Bank Operation Monitoring Interface", the animation running control commands are as shown in Fig. 7.

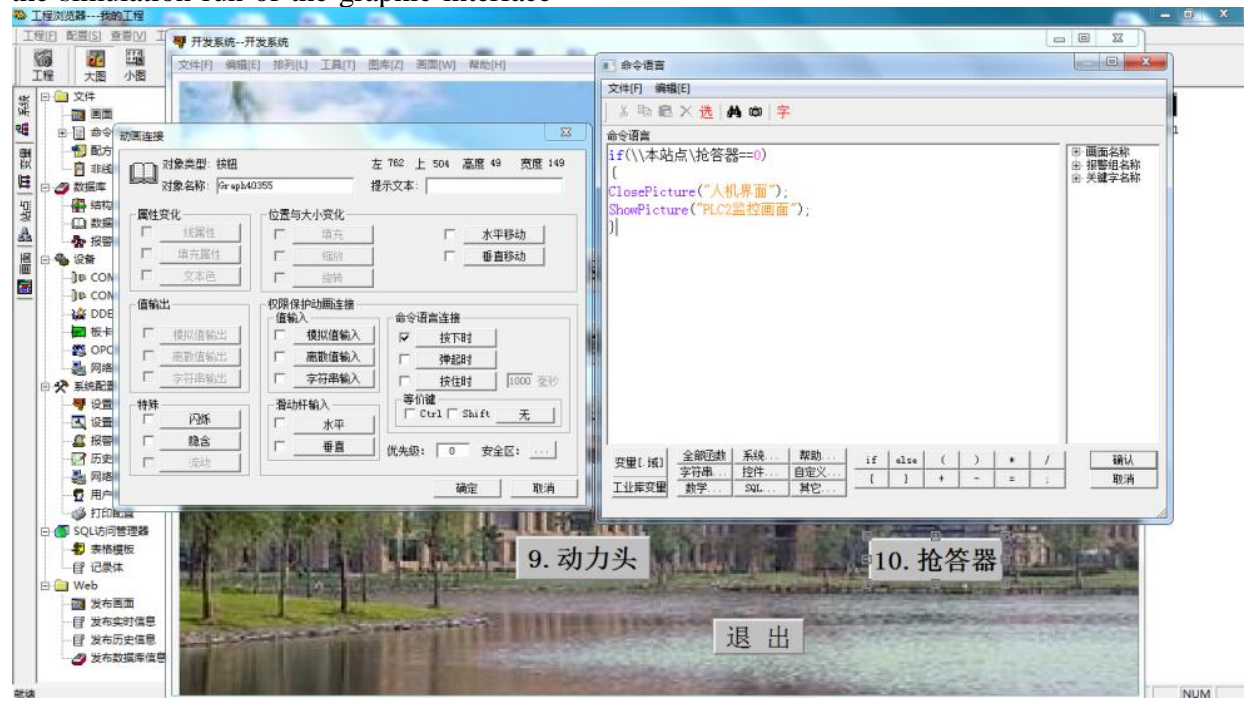

Fig. 7 Animation Running Command

\section{SYSTEM OPERATION ANALYSIS}

In order to check system experiment effect, it is necessary to set the communication system parameters, wherein the serial communication parameter Baud rate is 9600 , the data bits are 7, the even parity check bit and the stop bit are both 1 , the communication timeout is $3000 \mathrm{~ms}$ and the communication mode is RS-232. Afterwards, it is necessary to place PLC running state switch at "RUN" and start Kingview operation system TouchView to inspect and debug the project, thus to realize the control function of the system.

The application of this practical teaching device can well solve the low automation problem in the skill training andexamination for maintenance electricians. Meanwhile, the configuration technology is adopted to realize the function of student information login; the adoption of pictures, animations, words and monitored operation can well present the application of PLC in automatic control field, thus to realize human-computer interaction of the configuration interface and well integrate with the industrial remote control. In the colleges and universities paying more and more attention to theory and operability, such practical teaching devices act as the urgent devices for these colleges and universities to set up the intelligent practical courses for such majors as electrical engineering and automation in order to improve students' operability.

\section{REFERENCES}

[1] Qi Haixia,Xing Hang,Yang Xiuli. Semi-Physical Simulation of PLC Control System Based on Configuration Software [J]. Journal of Guilin University of Technology,2012,32(4):543-546.

[2] Zhang Shunxing,Zhang Yujie. Application of Configuration Software in the Electrical Control and PLC Teaching $[\mathrm{J}]$. China Modern Educational Equipment, 2009, (13).

[3] Yuan Qingping. Teaching reforms of Electrical Control and PLC Technique in High Vocational Colleges 
[J].Journal of Tongling Vocational \& Technical College, 2009, 8 (1).

[4] Zhu Jianhong. Application of Configuration Software in the PLC Electrical Control Training Teaching [J].China Science and Technology Information,2008,(6).

[5] Jin Shengai,Wang Wei. Application of PLC Simulation Software in the Electric Control of Machine Tool and PLC Course Design [J]. Liaoning Higher Vocational Technical Institute Journal,2008,10(10).

[6] Shen Shibin. Application of Communication Between Mitsubishi's PLC and PC [J].Microcomputer Information,2011(4):81- 83.
[7] Wang Hongmeng, Xie Jianjun, Zeng Yun,Bai Xuefeng. The Design of PLC-based Process Control Systems [J].Techniques of Automation and Applications, 2004(07).

[8] Liu Li.Process Control Experimental System Based on PLC and Kingview[J].Research and Exploration in Laboratory. 2014(04).

[9] Ren Xiaona,Wang Wangang,Li Lin,Ruan Wentao.Automatic Monitoring System for Water Level Based on PLC and Configuration Software[J].Value Engineering,2014 (21).

[10] $\mathrm{Li}$ Kai.The reform of PLC innovation experimental teaching Based on Configuration Technology [J]. Popular

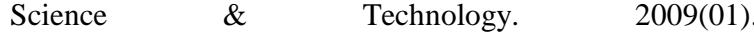

